\title{
EMPLOYEE DEVELOPMENT WITHIN THE EUROPEAN SOCIAL FUND IN POLAND IN THE 2007-2013 PROGRAMMING PERIOD FROM THE PERSPECTIVE OF THE FINAL BENEFICIARY - RESEARCH FINDINGS
}

\author{
Katarzyna Tracz-Krupa \\ Wrocław University of Economics \\ e-mail: katarzyna.tracz@ue.wroc.pl \\ DOI: 10.15611/noz.2017.4.04 \\ JEL Classification: M53, M16, F23
}

\begin{abstract}
Summary: The purpose of the paper is to explore the intervention of the European Social Fund in Poland in organizations that benefited from the funding in the 2007-2013 programming period. The study was conducted from the perspective of the final beneficiary. The study was carried out in 2017, based on the CATI method, in the group of two hundred employees of both private and public institutions that received financial support from the ESF to implement training and development activities. The results of the study describe both the expectations of the employees regarding development at the workplace, the possibilities offered by employers, and the types and forms of training financed by ESF in which they participated. Drawing on D. Kirkpatrick's model the paper refers to the effectiveness of the training. It also highlights the benefits from participation in the EU project from the employee perspective and ways to make use of the acquired qualifications by employers.
\end{abstract}

Keywords: employee development, final beneficiary, European Social Fund.

\section{Introduction}

The purpose of the paper is to review the interventions of the European Social Fund (ESF) in the development of employees in Poland in organizations that benefited from the funding in the programming period 2007-2013 from the perspective of the final beneficiary, i.e. the employees participating in the training and development offered by the employer. Its main goal aims at recognizing the employees' expectations regarding their growth in the workplace, identifying the forms of development in the ESF in which they participated, the benefits they gained from participating in the project, and the degree of use of the acquired qualifications by the employer.

Poland was allocated $€ 11.429$ billion from the European Social Fund over the period 2007-2013, which made the country the largest beneficiary of EU assistance among all the new Member States. The analyses carried out following the completion of the implementation of the Human Capital Operational Programme, which embraced all the interventions of the European Social Fund in Poland in the years 20072013, show that by the end of June 2015 nearly 47.8 thousand co-financing contracts were signed. The total value of public funds amounted to nearly PLN 50.6 billion. Over 1.06 million working adults participated in training projects atregional level [Sprawozdanie $z$ wdrażania... 2015]. Annual research conducted by PARP (Polish Agency for Enterprise Development) shows that every seventh entrepreneur in Poland benefited from EU subsidies for improving the qualifications of employees [Bilans Kapitału... 2013]. The scale of the phenomenon is substantial, however, there is a lack of qualitative data on the types and forms of training that were most often designated for a grant, as well as the level of satisfaction with participation in these activities and with their results.

In the subject literature there is little research on the development of employees in Central and Eastern European countries [Morley et al. 2016]. HRD is widely described in the international, comparative and cross cultural context [Garavan, Carbery 2012], however it rarely refers to countries that joined the 
European Union in 2004 and later on. An interesting comparative study on training practices in eight Central European countries was presented by M. Morley et al. It shows that the use of more developed training practices contributed to an improved organizational performance by reference to service quality, productivity, proficiency and innovation. [Morley et al. 2016]. The research did not include Poland. The author's research interests concern the development of employees on the basis of EU funding. Similarly to the case of HRD and employee development, there is no research on the use of EU funds for employee development in the new Member States. There is a case of spending EU funds on qualifications improvement in Portugal described in [Tomé 2012, 2013], as was presented by researchers in the UK [Devins, Johnson 2002; Keogh, Stewart 2001] and Spain [Cardenete, Delgado 2013]. In Central Europe, however, only research on Romania is available, which describes the irregularities in the management of EU projects by the managing institutions at national level [Zaman, Georgescu 2014; Pautu, Dogaru 2013]. Accordingly, the author's intention is to present the results of empirical study on the development of employees which was carried out in a group of 200 employees of public and private organizations in Poland. Importantly, the study focused on the employee's (not the employer's) perspective.

To meet the objective of the paper the author arranged its structure as follows: the introductory part focuses on the meaning of the basic terms used in the paper. Then, the methodology of own research and characteristics of the studied population are described. Following that, the results of the empirical research are presented. The final part highlights the conclusions of the study and possible directions for further exploration.

\section{Definition and scope of the basic concepts used in the paper}

The paper refers to three basic concepts: the development of employees, the final beneficiary and the European Social Fund (ESF), whose meanings and definitions are worth mentioning at this point.

For the purpose of the article the distinction between training, development and HRD has been defined [Tracz-Krupa 2017, p. 305]. Training and development focus on the priorities used to develop employees and the intensity and diversity of training and development practices, whereas Human Resources Development (HRD) focuses on the strategic dimensions of training and development practices [Garavan et al. 2008, p. 615]. According to Heraty and Morley [1998], training and employee development policy can be treated as a reflection of the organization's philosophy towards its human resources and something which may influence the priorities, standards and scope of its development activities. In the opinion of Garavan and Morley [2006], there are on-going underlying ambiguities connected with the question of contribution. HRD has evolved from the construct that has been dominated by three theoretical perspectives: (1) the structural-functional that places an emphasis on skill gap analysis, (2) the performance deficiencies and systems perspectives that underline the identification of elements of the HRD system and the interaction between these subsystems and (3) the network/actor perspective that conceptualizes HRD as a dynamic network of interactions between actors and interest groups [Garavan, Heraty, Morley 1998, p. 115] to the global HRD. During the last two decades, HRD research has broadened from its traditional focus on understanding learning by individuals and organization to examining HRD in an international context which allows to distinguish three trajectories of HRD: international, comparative and cross cultural. International HRD focuses on understanding HRD in the context of the multinational corporation; comparative HRD investigates national HRD policies, skill formation systems and processes in a number of countries as it is important to enhance the theoretical base of HRD, and cross cultural HRD researches the cultural distinctiveness of practices, beliefs and values shared by a country. This leads to the emergence of a global HRD construct that captures the challenges faced by globalization processes [Garavan, Carbery 2012].

The second term used in the article is the final beneficiary (FB). This is a natural or legal person who directly uses support from the EU. In training projects, the employees of the organizations that apply for EU grants have the status of final beneficiaries.

The last term used in this article is the European Social Fund. The European Social Fund (ESF) is the first and basic structural fund of the European Union. It was created in $1957^{1}$ to increase the opportunity to become employed in the European Union through the promotion of employment and increase in mobility of the workforce [Tracz-Krupa, 2015, p.246]. Ever since then, the ESF has been the first and foremost financial instrument of the employment policy [Grewiński 2003, p. 9] and the development of human resources in the EU. Since the beginning of the 1960s it has

\footnotetext{
${ }^{1}$ It was appointed on the basis of art. 123 of the Treaty of Rome, yet the relevant implementing acts entered into force in 1960.
} 
Table 1. Comparison of ESF policy in 2000-2020

\begin{tabular}{|c|c|c|c|}
\hline \multicolumn{4}{|c|}{ European Social Fund } \\
\hline 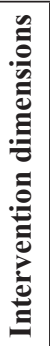 & $\begin{array}{l}\text { Development of human } \\
\text { resources, improvement of the } \\
\text { labor market operation, } \\
\text { prevention of unemployment } \\
\text { - Only program projects and } \\
\text { combating unemployment }\end{array}$ & $\begin{array}{l}\text { - Implementation of the European Employment } \\
\text { - Strategy guidelines and their modernization } \\
\text { - Problems of the aging population } \\
\text { - Preventing the negative effects of globalization } \\
\text { - Emphasis on employee adaptability } \\
\text { - Prolonging the age of activity on the labour market } \\
\text { - Prevention of unemployment, poverty, social } \\
\text { exclusion and discrimination }\end{array}$ & $\begin{array}{l}\text { - Promoting employment and } \\
\text { professional mobility } \\
\text { - Investing in education, skills and } \\
\text { lifelong learning } \\
\text { - Promoting social inclusion and } \\
\text { combating poverty } \\
\text { - Enhancing institutional capacity } \\
\text { and the effectiveness of public } \\
\text { administration }\end{array}$ \\
\hline \multirow{4}{*}{ 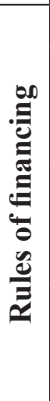 } & $2000-2006$ & $2007-2013$ & $2014-2020$ \\
\hline & $\begin{array}{l}\text { Maximum co-financing from ESF } \\
\text { funds: } 75 \%\end{array}$ & Maximum co-financing from ESF funds: $85 \%$ & $\begin{array}{l}\text { Maximum co-financing from ESF } \\
\text { funds: } 85 \% \text { and for the Mazowieckie } \\
\text { voivodship } 80 \%{ }^{*}\end{array}$ \\
\hline & $\begin{array}{l}\text { The period of spending ESF funds: } \\
\text { rule } n+2\end{array}$ & $\begin{array}{l}\text { The period of spending ESF funds: } \\
\text { rule } n+3 \text { in years } 2007-2010 \\
\text { rule } n+2 \text { in years } 2011-2013\end{array}$ & $\begin{array}{l}\text { The period of spending ESF funds: } \\
\text { rule } n+3\end{array}$ \\
\hline & Multi-funding & $\begin{array}{l}\text { One program - one fund, the principle } \\
\text { of co-financing from two funds (cross financing) } \\
\text { to a limited extent }\end{array}$ & $\begin{array}{l}\text { One program - one fund, the principle } \\
\text { of co-financing from two funds (cross } \\
\text { financing) to a limited extent }\end{array}$ \\
\hline
\end{tabular}

* In the priority axis of social innovation, the co-financing was increased by 10 p.p., i.e. to $95 \%$ within less developed regions and to 90\% in more developed regions. More on this subject in: [Program Operacyjny... 2014, p. 227].

Source: own work based on [Hryniewicka 2015, pp. 96-97; Barcz, Kawecka-Wyrzykowska, Michałowska-Gorywoda 2012, p. 279; [Program Operacyjny... 2014, p. 227; Barcz, Kawecka-Wyrzykowska, Michałowska-Gorywoda 2016, pp. 239, 243-244].

evolved along with the entire structural and employment policies of the European Union ${ }^{2}$. Its evolution took two directions. Firstly, it gradually integrated with other ESF structural instruments to enhance cooperation and coordination of all the structural instruments of the EU with respect to both the goals and management mechanism [Dormiter, DrelichSkulska, Marciszewska 2005, p. 69]. Secondly, the European Social Fund continued to place more emphasis on international goals which were coherent with the European Employment Strategy $^{3}$ and recognized by all Member States. The complex evolution of the ESF can be divided into four time phases: 1958-1971, 1972-1983, 1984-1989 and 1990 onwards. Each of the phases was directed by a set of legislation. The current one started in 1990 with the "Reform of the European Structural Funds" and has evolved to the successive "Programming Phases" of the European Union, namely 1990-1993, 1994-1999, 2000-2006, 2007-2013 and 2014-2020 [Tomé 2012, p. 180]. In these phases, the ESF has worked through national programs called Operational Programs (OPs), defined by the Member States in partnership with EU bodies [Tomé 2013, p. 337]. A list of the most important changes in the ESF policy in the last two decades is presented in Table 1.

Upon entering the EU structures Poland was obliged to comply with all EU directives and to implement changes in Polish law based on the guidelines of the EU institutions ${ }^{4}$.

The study carried out for the purpose of this article concerned the use of ESF resources in Poland over the period 2007-2013 under the framework of the Human Capital Operational Programme.

\section{Methodology and scope of the conducted study}

The study was carried out in 2017 among a group of 200 employees who were the final beneficiaries, working in both private and public organizations that received EU funds from the ESF (European Social Fund). The author of the study applied a non-probability, purposive sampling. The criterion for selection was the implementation of at least one EU project in the financial perspective 2007-2013 for co-financing

\footnotetext{
${ }^{2}$ More on the evolution of the ESF in: [Grewiński 2001, pp. 61-126].

${ }^{3}$ The European Employment Strategy is a set of priorities and tasks of EU countries in the area of employment. It was founded in the Amsterdam Treaty in 1997 and built around four pillars: employment, including support for lifelong learning and career counseling; entrepreneurship; adaptability of employees and employers and equal opportunities. The main objectives of the European Employment Strategy were: striving for full employment, improving the quality and productivity of work, and strengthening social cohesion and integration [Kierzkowski 2009, p. 27].

${ }^{4}$ See, for instance: [Molek-Winiarska 2016, pp. 71-87].
} 
training and development activities. The public database of organizations that implemented EU projects was used. The subject of interest of the author was the Human Capital Operational Programme, in particular Priority V and Priority VIII. By narrowing down the criteria, a list of companies and local government authorities whose employees were potential research object was created. Following this step, the snowball method was used. Experts in the field of EU funds were asked for help in reaching organizations that would meet the study criteria. In the end, a hundred organizations spread across the country qualified for the study. They were diversified by size: micro, small, and medium-sized organizations. The two main categories of entities that applied for the EU funds included local government authorities and micro, small and medium enterprises (SMEs). Finally, the sample contained 56 public institutions $(n=56 \%)$ and 44 private organizations from the sector of small and medium enterprises $(n=44 \%)$.

The data were collected from a series of semistructured computer assisted telephone interviews (CATI) with employees of organizations that received EU funding. The structure of the questionnaire was created based on a set of organized activities in which the first issue that was queried were the expectations and plans for development from EU funds, in the implementation phase - the types of training in which FB participated and finally, in the control phase, the assessment of the effectiveness of training, its benefits and ways of using the acquired qualifications by the employers. The detailed scope of the questions and answers can be found further on in the article. The interviewees could select a few possible answers. The research aimed at providing well-grounded and rich descriptions and explanations of employee development in organizations as a result of the intervention of the European Union funds from the perspective of the beneficiary. In this study a qualitative approach was applied [Bogdan, Bicklen 2002], thus making the evaluation analysis largely narrative.

A limitation of the research procedure is the fact that the interpretations of the test results, statements and conclusions made in this article refer only to the group of the studied population of 200 final beneficiaries. Due to the qualitative nature of these surveys, as well as the size of the sample, it is not legitimate to generalize the results of the research and refer them to a wider population of EU project participants. Nevertheless, the author hopes that her conclusions and reflections will become part of the current discussion on the development of human resources relating to ESF funds.

\section{Characteristics of the studied population}

The group of the respondents constituted mainly specialists $(48 \%)$ and managerial staff $(50 \%$ of the studied population). Women (68\%), more frequently than men (32\%), were the beneficiaries of the training activities. Persons from the age group 36-45 years (52\% of the respondents) most frequently participated in the ESF training and development activities, followed by employees aged 26-35 (25\%) and 46-55 $(16 \%)$. Persons over 55 years of age were least likely to participate in the ESF project. The final beneficiaries had over five years of experience $(40 \%)$ or even more than ten years ( $51 \%$ of the studied population). The respondents were, in the vast majority $(95 \%)$, persons with a higher education. Education is one of the most important criteria used in comparative research that determine the development and competitiveness of businesses, regions or countries. With respect to this matter, Poland outperforms significantly the EU average, which should be a positive. However, the comparison of the participation of Poles in lifelong learning with other European countries falls unfavorably. From the research at macroeconomic level, it turns out that the percentage of adults participating in different forms of education is almost twice as low as the EU average and 4-5 times lower than in Scandinavia [Kwiatkowska-Ciotucha 2013].

\section{Presentation of own empirical study results}

The first research question explored the issue of the expectations of employees regarding development in the workplace; $95 \%$ of the respondents, both in the public and SME sector, stated that they expected their employer to provide them with opportunities for development. Employees expect that their workplace will allow them to achieve goals not only related to financial motivation, but that they will also have the opportunity to improve their qualifications, so that the goals related to non-financial motivation will be achieved. The next question asked about the forms of development in which the employees would be interested in. The vast majority of employees, $84 \%$, were interested in training. Over half of the respondents expected promotion, $46 \%$ aimed at career development and $8 \%$ at an increased scope of work responsibility. The distribution of responses in public organizations and SMEs was similar. It is often required to obtain certain qualifications to apply for a promotion or, more broadly, to pursue a career path, therefore the interest in this form of development appears most important. 
Next, the respondents were asked whether their employer offers opportunities for development; $75 \%$ of the respondents selected a positive answer, 22\% were of the opinion that their employer at times provided opportunities for development. Only 3\% of employees stated their workplace did not create opportunities to improve their qualifications or to shape their career. It should be noted that the research covered the organizations that benefited from EU funding; therefore employers could offer their employees participation in training. The report of the fifth edition of the research entitled "The Balance of Human Capital" implemented by PARP(Polish Agency for Entrepreneurship Development) in 2012-2014 shows that the vast majority of Poles, as much as $63 \%$, in no way improved their qualifications even by self-education; $37 \%$ of Poles aged 18-59 / 64 developed their qualifications through courses, training, selfstudy or formal education (about 9.2 million people). Among these:

- $20 \%$ (4.8 million) of Poles took part in courses, training, workshops, lectures, seminars, conferences, internships or postgraduate studies, of which $6 \%$ (1.4 million) participated in mandatory $\mathrm{OSH}$ and fire safety courses, and 14\% (3.5 million) improved their qualifications through non-obligatory courses and training;

- $14 \%$ (3.4 million) of respondents participated in formal education.

At the same time, research shows that $61 \%$ of the working population did not feel the need to improve their qualifications. Some respondents indicated lack of time or lack of motivation [Turek, Worek 2015, pp. 8-9].
The next research question asked about the forms of development in which the respondents participated. All employees were supported by an ESF training project; $75 \%$ of the respondents participated in training funded by their employer, while $28 \%$ of the respondents had the scope of work responsibility increased and $19 \%$ were promoted, $12 \%$ of employees believed that the employer was shaping their career. At this point one may be inclined to state that in the studied organizations, employees had the opportunity to develop through: improving their qualifications, structuring their work and nearly a third through promotion or shaping their career. The OECD evaluation report on skills development and training in SMEs in Poland shows that high costs $(78 \%$ of responses) and lack of public support (60\%) are the main barriers to employee participation in training [Kubisz 2010, p. 44].

Due to the subject of the research, the author's attention was drawn to training financed by the ESF. The respondents were asked to indicate the types of ESF training in which they participated (Figure 1).

Thus $61 \%$ of the respondents took part in human resource management training in different areas of HR. Computer training (41\%), foreign language (40\%) and legal $(36 \%)$ were very popular; $22 \%$ of employees participated in finance training and $20 \%$ in specialist training. In addition, the EU grants funded bachelor's, master's and post-graduate studies (18\% of responses), counseling (14\%) and coaching and mentoring (9\%). By analyzing two dependent variables: type of organization and type of training, it can be concluded that the public sector takes advantage of legal training more often than organizations in the SME sector $(53 \%$

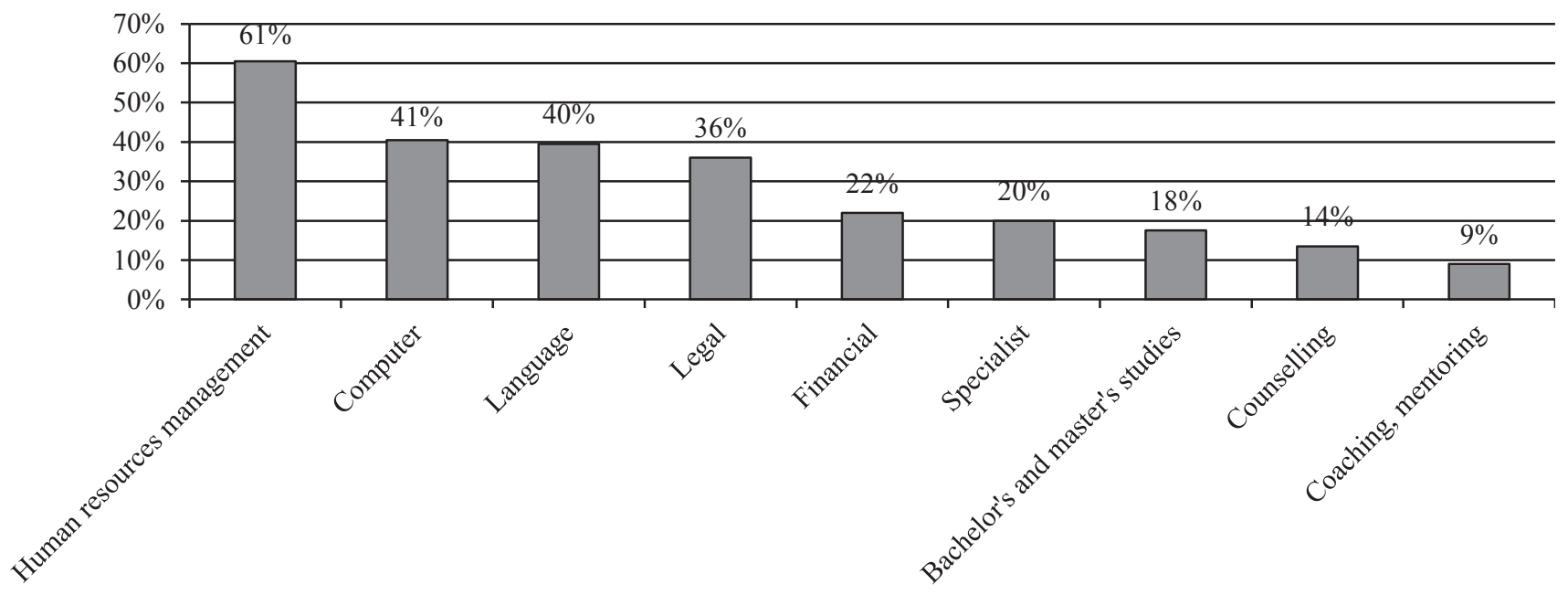

Fig. 1. Employee participation in particular training funded by the ESF

Source: own study. 
vs. $15 \%$ ). This also appears in the case of undergraduate, graduate and postgraduate studies $(27 \%$ and $6 \%$; see Figure 2). Besides human resource training, legal training attracted most interest among office workers. This was due to the ongoing changes in legislation, whose knowledge is required at most positions in public administration offices.

The research carried out by other authors (e.g. A. Podgórniak-Krzykacz and M. Kalisiak-Mędelska) shows that the subject of training in local government usually covers the scope of the current functioning of the institution and its administration. Most frequently they are about enacting a new legislation [2016]. According to T. Kowalski, other training, especially in management, psychology or communication, rarely appear in local administration [2006]. The author's research shows that EU projects have provided opportunities for local government employees to participate in training of not only a legal nature, but also of broadly acknowledged human resource management.

In companies, compared to local authorities, foreign language training was more popular (49\%) than IT (32\%), also computer ( $43 \%$ vs. $38 \%$ in IT) and specialist skills ( $32 \%$ versus $11 \%$ in IT) .

The next step in the research procedure was to pose the question on the ways to identify the training needs for the purpose of an ESF project. Most of the staff pointed out the training in which they would be interested in the EU project (67\% of responses). In over half of the organizations (52\%), top management assigned their staff to training. Only $12 \%$ of the training cases resulted from professional development plans and 6\% from regular staff appraisal. On this basis it can be concluded that the ESF training and development projects took place on an occasional basis and their theme scope was defined without linking to other elements of the personnel function such as performance appraisal. The research conducted by W. Karna in public administration shows that there are no formal assessment procedures regarding training needs nor systems for evaluating training effectiveness [2011]. OECD research carried out among 511 SMEs in Poland shows that most of the enterprises did not have training plans, and only $20 \%$ had budgets for any development activities [Kubisz 2010, p. 36].

In the literature on the subject, research in the sector of small and medium enterprises (SMEs) and large organizations is separate. The dominant belief is that SMEs have their specificity and that the activities in the field of human resources management, including the area of development, are different from those popular in large organizations. Hill and Stewart's research shows that small and medium organizations are characterized by a short-term perspective and spontaneity in the implementation of the policy of human resources development [1999, p. 107]. The informality and flexibility of development activities in the SME sector has been thoroughly characterized in the studies of Gibb [1997] and Chaston [1997]. Other researchers, for instance Westhead and Storey [1997], argue that training in small organizations is absent. Hill and Stewart are of the opinion that the

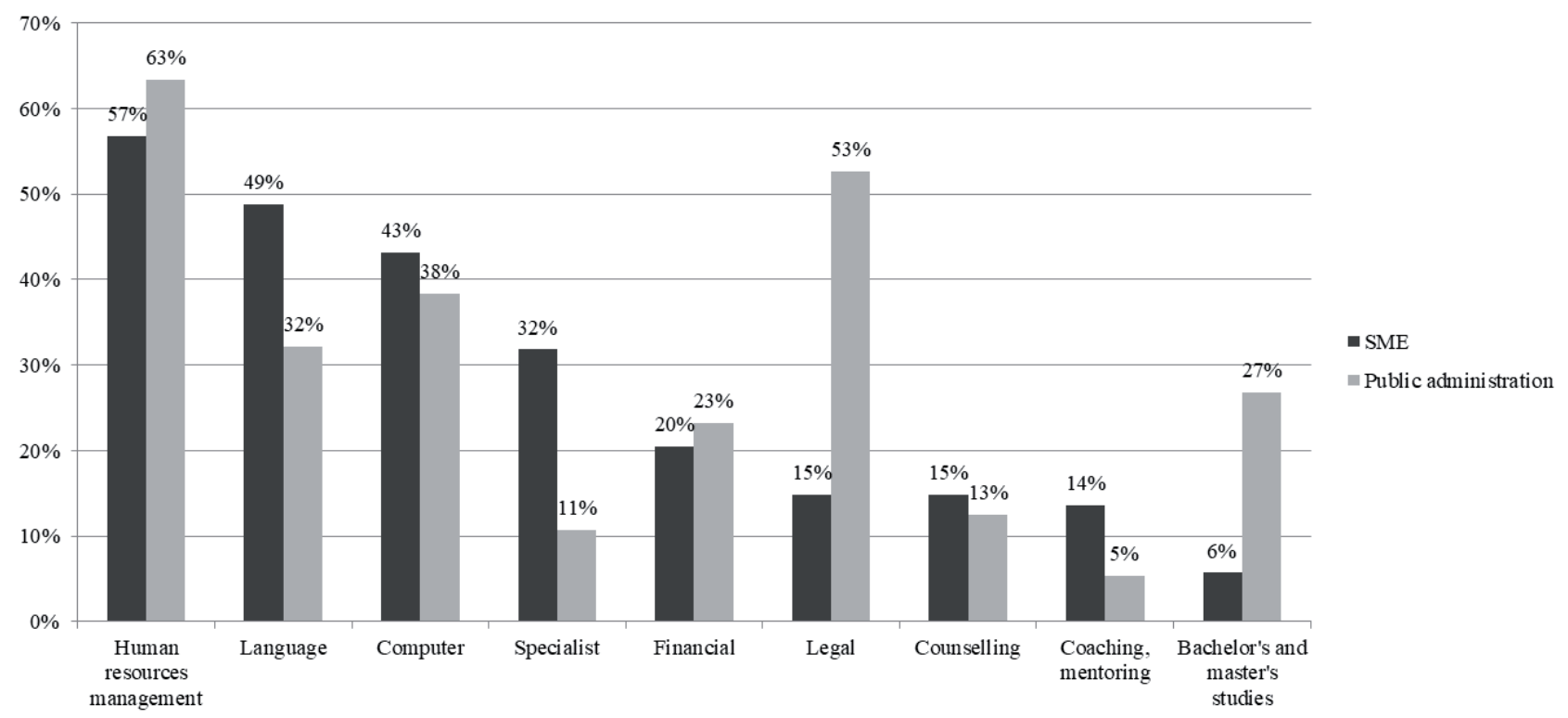

Fig. 2. Employee participation in particular type of training and type of organization

Source: own study. 
trainings are designed to solve specific problems in an organization and not to improve the qualifications of employees [1999, p. 109]. The extensive comparative studies of Brown, Murphy and Wade on e-learning in organizations prove that $67 \%$ of large enterprises use this form of education, while this number for small and medium enterprises amounts to a mere $20 \%$ [2006, p. 425]. The factors characterizing the area of employee development in SMEs include: informality, short-term perspective, focus on solving current problems, emphasis on development of specific skills and organizational knowledge, and lack of professional organization of training [Trochimiuk 2013, p. 127].

The next step in the research process was the question of learning effectiveness; $82 \%$ of the staff responded that training effectiveness was tested, $18 \%$ provided a negative response. According to U. Pauli's research on the professionalization of training in small and medium-sized enterprises in Poland, similarly, $24 \%$ of SMEs fail to evaluate the effectiveness of training [Pauli 2014]. Later, the respondents were asked to indicate the ways the training effectiveness was evaluated based on D. Kirkpatrick's Model. The model was created to define the four levels of training evaluation : (1) the reaction of the participants and their thoughts about the training experience; (2) the participant's resulting learning and increase in knowledge from the training experience; (3) the participant's behavioral change and improvement after applying the skills on the job; and (4) the results or effects that the participant's performance has on the business [Kirkpatrick, Kirkpatrick 1994].

Thus $71 \%$ of the staff responded that the level of reaction was examined. Only $27 \%$ of respondents were of the opinion that the effects of training were verified on the learning level and only $7 \%$ on the behavioral level. The response level is most often verified by the questionnaire that the trainees fill out after completing their training, this is also required at the control stage from both the organization implementing the project and the training institution. Based on that, it can be stated whether the employees remember they participated in the study at the level of reaction, yet the question remains as to whether it was a procedural requirement of EU projects or the SMEs and local governments were actually interested in reaction of the participants to the training. The level of knowledge, according to the employees, was checked only in fewer than $1 / 3$ of the cases of training.

According to U. Pauli's research in the SME sector, a training questionnaire measuring the level of reaction was used in only $19 \%$ of organizations, and effectiveness on the level of learning in $18 \%$ of organizations. Only $7 \%$ of the surveyed companies performed behavioral evaluations. At the same time, $35 \%$ of respondents declared that they acquired new knowledge and new skills in the workplace [Pauli 2014]. The practice of organizations operating both in Poland and worldwide shows that research on the effectiveness of training and development programs is most commonly carried out at level 1 , i.e. reaction level. On this basis, the managerial staff draws conclusions about the correctness of conducting employee development policy in the organization. If the participants' satisfaction is high, it is regarded that the employee qualifications improvement program enhances the quality of human capital, which contributes to the competitiveness of the organization. Research shows that the evaluation of programs only at the level of reaction brings a limited value. There is a need to evaluate program effects at higher levels in order to examine its effectiveness and efficiency [Danielewicz 2014, p. 310].

At the last stage of the final beneficiary survey, there was a question of whether they noticed the benefits of participating in the ESF-funded project. The vast majority, $98 \%$ of respondents, gave a positive answer. Then the respondents were asked to identify the benefits they gained from participating in the EU project (Figure 3).

The greatest number of respondents, $68 \%$, indicated that they increased their knowledge and improved their professional qualifications (65\%). Nearly half of the respondents (49\%) stated that their skill level were raised. The results of the study correspond to the answers to the question about employees' expectations of development in the workplace. Additionally, the declared benefits of participation in the EU project were: increased motivation and involvement (19\%), better work performance (16\%), higher level of self-fulfillment at work $(14 \%)$ or increasing chances on the labour market (11\%).

When analyzing the benefits for the two types of organizations it can be noticed that employees in local government institutions pointed to an increase in knowledge more frequently than their counterparts in SMEs ( $71 \%$ vs. $64 \%$ in SMEs) or improvement of formal qualifications $(70 \%$ vs. $58 \%)$. The staff of SMEs on the other hand, highlighted skills improvement (53\%), also achieving better performance at work ( $24 \%$ vs. $14 \%)$ and lower stress levels at workplace $(17 \%$ vs. $5 \%)$. This is linked to the type and specificity of the organization. In businesses, performance indicators and achieving higher results play a major role, while in public organizations, from the perspective of employees, it is formal qualifications that count. 


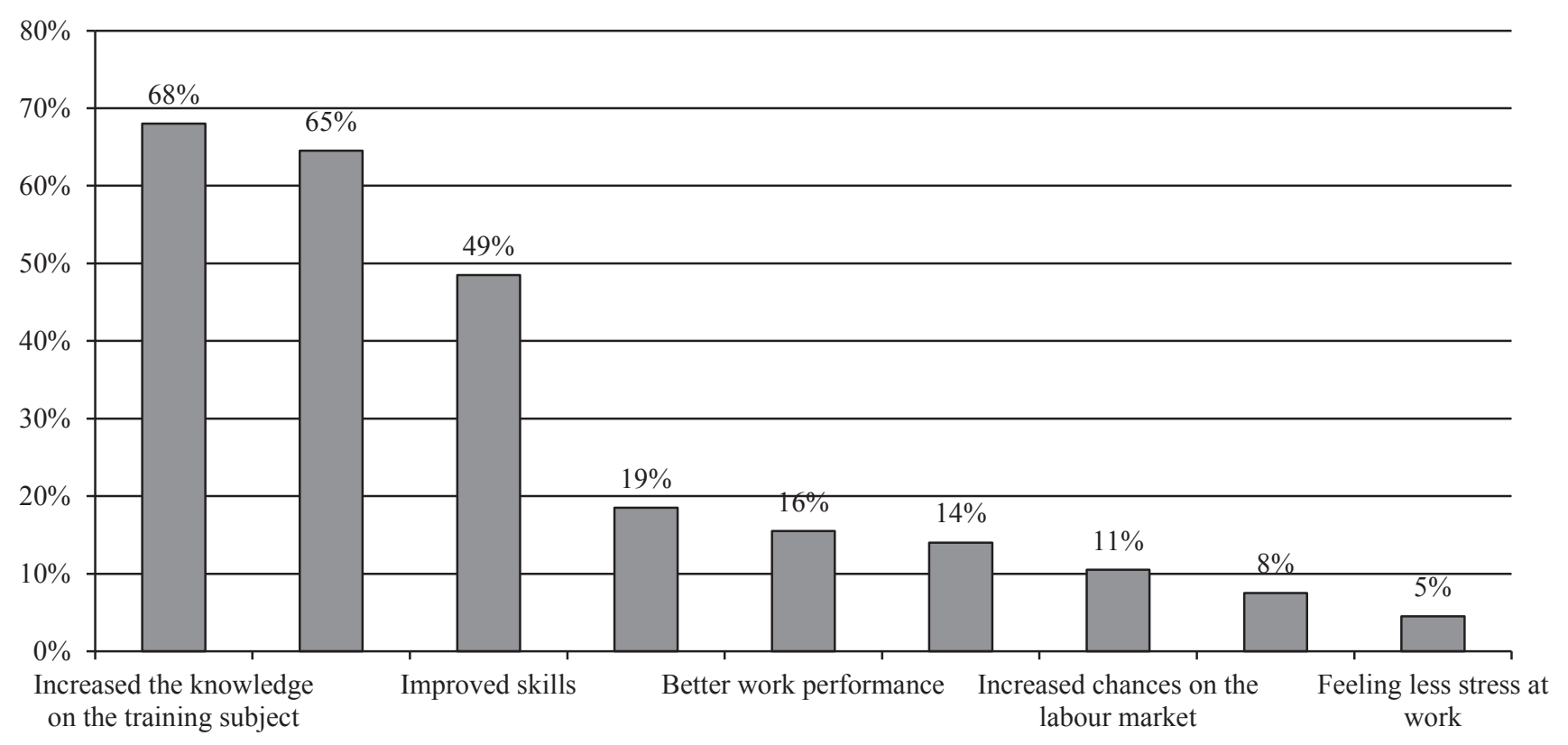

Fig. 3. Classification of benefits from participation in an ESF project

Source: own study.

Evaluation carried out by the OECD among enterprises from the SME sector presents similar results. $35.4 \%$ of respondents pointed to skills upgrading and $45.5 \%$ to career development opportunities as the benefits from participation in training, while $90 \%$ of low-skilled personnel were not able to notice the benefits from participation in training [Kubisz 2010, pp. 41-42]. The respondents in the author's research had mainly higher education and were aware of the importance of lifelong learning. On a national scale, this situation is unfavorable. In Poland, the value of lifelong learning index amounted to $3.8 \%$ in 2014 [Sprawozdanie końcowe ... 2017, p. 15]. There is a prevailing belief that knowledge that has been acquired is sufficient and there is no need to further expand it. The next research question asked about the qualifications that were improved in the EU project. $59 \%$ of the respondents marked an increase in interpersonal skills, $38 \%$ in foreign language, $36 \%$ in IT, and $35 \%$ in law. Following these responses, the respondents pointed to increase in specialist skills $(20 \%)$, increase in finance knowledge $(18 \%)$ and improvement in managerial skills $(15 \%)$.

Looking closer at the type of organization, it can be observed that the employees of public organizations attached importance to acquiring specialized skills (58\% of respondents) and increasing their knowledge of the law (56\%). In turn, SME employees, in addition to increasing their specialized skills $(59 \%$ of the respondents), pointed to interpersonal qualifications $(45 \%)$, including managerial qualifications $(32 \%)$. The type of improved qualification is related to the training in which the employees participated, dominated by foreign languages, IT and managing human resources. There is a high correlation between the type of training in which the final beneficiaries participated and the qualifications they obtained, which should be interpreted as the proper spending of EU funds. The strategic goal which was set in Human Capital Operational Programme projects, focused on increasing the adaptability of employees so they would fulfill the needs of the labor market. This goal was achieved.

The next step in the research procedure was the question of whether the organization in which the respondents were employed makes use of the qualifications acquired in the ESF project; $71 \%$ of the respondents claimed that the scope of their work duties increased, $15 \%$ were promoted, while $17 \%$ were of the opinion that the organization did not use the qualifications they acquired. The results of the research indicate that the result of the ESF training and development project was not just the improvement of qualifications of the employees, but also the structuring of work and staff rotation. One positive fact that should be noted is that organizations use the qualifications gained by employees as part of the EU project through the structuring of work.

Lastly, the respondents were asked whether the ESF-funded training and activities met their expectations and whether they would recommend other people and institutions to implement such a project. The majority of the respondents, $98 \%$, expressed their satisfaction with the project. The same question was 
asked among SMEs employees in the UK who benefited from ESF in the UK. The projects met their expectations but their impact on organizational performance indicators was insignificant [Devins, Johnson 2002]. Other studies conducted in the UK also show that the training of employees in SMEs was significant but not of strategic importance to the development of companies [Keogh, Stewart 2001]. The vast majority, $97 \%$ of all the respondents, would recommend implementing the ESF training and development project to other people or institutions.

\section{Conclusions and implications for further research}

Summarizing the results of the study conducted in a group of 200 employees, the final beneficiaries of a training and development ESF project, the following general conclusions may be drawn:

1. The vast majority of employees expected their employees to ensure opportunities do develop in the workplace.

2. Most of the respondents were interested in training but also in rotation within a company and shaping their career.

3. Three-quarters of the respondents were offered the possibility to develop through training, but in a smaller number, through work structuring or rotation.

4. All respondents were beneficiaries of an ESF project that offered training in human resource management, foreign languages, IT, legal, finance and specialist knowledge.

5. An analysis of training needs was conducted once for the purpose of the EU project by assigning employees to training or employee application for participation. The training and development activities were not connected with other elements of the personnel function.

6. The informative and demonstrative methods were dominant in training, followed by simulation methods.

7. The effectiveness of training and development by D. Kirkpatrick was evaluated on the level of reaction but rarely on the level of learning.

8. The vast majority of respondents observed the benefits from participation in the EU project by increase in specialist knowledge and in professional qualifications, and also an increase in motivation and work involvement.

9. The interpersonal, foreign language and IT qualifications were most frequently indicated by the respondents.
10. Another result of the implementation of the project was, according to the respondents, work structuring and employee rotations.

11. With respect to the planned training and development activities, the projects met the employees' expectations fully or to some extent and would be recommended to other people or organizations.

Analysis of the employee development from the perspective of the final beneficiary helped to diagnose the following dysfunctional areas:

1. Planning of training and development was performed ad hoc. The analysis of training lacks an in-depth analysis of the needs of organization, tasks and personal analysis.

2. In the analysis of training needs, decision-making on the selection of the ESF training was based on interviews. A scant spectrum of methods and techniques was used for analyzing human resources in organizations. These methods and techniques can be used individually or in combination with heuristic techniques.

3. The decision on assigning and employee to training was taken by the direct supervisor. The participation of other players, referred to as the training quintet, could ensure a better performance in the training process.

4. Analysis of the effectiveness of the training did not meet the main employee objective - it did not provide reliable information on how much the gap in knowledge, skills and interpersonal skills of the staff involved in the training was reduced.

5. The lack of a complete analysis of the effectiveness at the level of reaction, learning and behavior, according to D. Kirkpatrick, limited the overall evaluation of the training project. This is because the above levels of evaluation of training projects are linked together in a logical sequence of outcomes. Training exerts certain reactions that trigger learning processes, which in turn lead to specific behavioral changes that are reflected in the performance results of particular organizational units and the organization as a whole.

A fundamental error in the approach to ESF training and development projects was the lack of a systemic approach that is distinguished by the holistic and integrative perception of training in such a way that they create a mutually interrelated and interacting set of elements designed to achieve a specific goal [Koziński, Listwan, 2005]. What is more, there was a lack of systemic approach to a person as a complex being, who has the need to participate in decision-making and in execution of important tasks, to contribute to the organization, but 
also to self-control and even creative activities [Koziński, Listwan 2005 ].

Finally, it should be noted that the results of the research presented in this article refer to a population of 200 employees. Due to the qualitative character of this study as well as the sample size, it is not possible to generalize the results of the study and refer them to a wider population of organizations and workers that received funding for the implementation of ESF training activities. Nevertheless, the author of the paper hopes that the conclusions and reflections will be integrated into the debate on the development of the staff of SMEs and local government administration using ESF resources.

Bearing in mind the further direction of exploration, with respect to this research, comparative studies on employee development in several different countries in the Central Eastern European (CEE) region within ESF are essential and necessary. They could serve to establish basic patterns in policy provision and could show practices and patterns at an organizational level and their underlying sociocultural legitimacy. What is more, they could inform and assist other, later transitioning and EU joining countries, in the development of their human capital. There are important structural, institutional and configurational differences with essential differences in HRM and HRD practices in CEE arising from historical and ideational legacies [Morley et al. 2016]. As there are similar actions taking place in the distribution of ESF within Operational Programmes in EU Member States, national patterns pertaining to employee development and HRD could be characterized by specific enduring elements to show the trajectory of HRD in a particular country.

\section{Bibliography}

Barcz J., Kawecka-Wyrzykowska E., Michałowska-Gorywoda K., 2012, Integracja europejska w świetle Traktatu z Lizbony, PWE, Warszawa.

Barcz J., Kawecka-Wyrzykowska E., Michałowska-Gorywoda K., 2016, Integracja europejska w okresie przemian. Aspekty ekonomiczne, PWE, Warszawa.

Bilans Kapitału Ludzkiego w Polsce. Najważniejsze wyniki III edycji badań BKL z 2012 roku, 2013, PARP, Warszawa.

Bogdan R.C., Bicklen S.K., 2002, Qualitative Research for Education: An Introduction to Theory and Methods, Allyn \& Bacon, Boston.

Brown L., Murphy E., Wade V., 2006, Corporate eLearning: human resource development implications for large and small organizations, Human Resource Development International, no 3, pp. 415-427.

Cardenete M.A., Delgado M.C., 2013, Analysis of the impact of the European Funds in Andalusia in 2007-2013 using a General Equilibrium Model, Modern Economy, no 4, pp. 448-452.

Chaston I., 1997, Small firm performance: assessing the interaction between entrepreneurial style and organizational struc- ture, European Journal of Marketing, no 31 (11/12), pp. 814-831 .

Danielewicz D., 2014, Organizacja procesu rozwoju kompetencji [in:] Juchnowicz M. (ed.), Zarzadzanie kapitatem ludzkim. Procesy-narzędzia - aplikacje, PWE, Warszawa

Devins D., Johnson S., 2002, Engaging SME managers and employees in training: lessons from an evaluation of the ESF Objective 4 Programme in Great Britain, Education +Training, vol. 44, no 8/9, pp. 370-377.

Dormiter M., Drelich-Skulska B., Marciszewska A., 2005, Jak umiejętnie zarządzać projektami EFS, Wydawnictwo Przecinek, Wrocław.

Garavan T.N., Carbery R., 2012, A review of international HRD: incorporating a global HRD construct, European Journal of Training and Development, vol. 36, no 2/3, pp. 129-157.

Garvan T.N., Heraty N., Morley M., 1998, Actors in the HRD Process. An explanatory Study, International Studies of Management \& Organisation, vol. 28, no 1, pp. 114-135.

Garavan T.N., Morley M., 2006, Re-dimensionalising boundaries in the theory and practice of human resource development, Journal of Learning and Intellectual Capital, vol. 3, no 1, pp. 3-13.

Garavan T.N., Wilson J.P., Cross C., Carbery R., 2008, Mapping the context and practice of training, development and HRD in European call centres, European Journal of Training and Development, vol. 32, no 8/9, pp. 612-728.

Gibb A., 1997, Small firms training and competitiveness: building upon the small business as a learning organization, International Small Business Journal, no 15(3), pp. 13-29.

Grewiński M., 2001, Europejski Fundusz Społeczny jako instrument integracji socjalnej Unii Europejskiej, WSP TWP, Warszawa.

Grewiński M., 2003, Europejski Fundusz Społeczny w Saksonii. Wnioski dla Polski, Instytut Spraw Publicznych, Warszawa.

Heraty N., Morley M.,1998, Training and development in the Irish context: Responding to the competitiveness agenda?, Journal of European Industrial Training, vol. 22, no 4-5, pp. 190-204.

Hill R., Stewart J., 1999, Human resource development in small organizations, Human Resource Development International, no 2:2, pp. 103-123.

Hryniewicka M., 2015, Wplyw funduszy unijnych na rozwój sektora MSP w Polsce w latach 2007-2013, Difin, Warszawa.

Karna W., 2011, Zmiany w zarzadzaniu zasobami ludzkimi $w$ administracji samorzadowej, Monografie i Studia Instytutu Spraw Publicznych Uniwersytetu Jagiellońskiego, Kraków,

Keogh W., Stewart V., 2001, Identifying the skill requirements of the workforce in SMEs: findings from a European Social Fund project, Journal of Small Business and Enterprise Development, vol. 8 , no 2 .

Kierzkowski T., Janowska A., Knopik R. (ed.), 2009 Fundusze strukturalne oraz Fundusz Spójności, Wydawnictwo C.H. Beck, Warszawa.

Kirkpatrick D.L., Kirkpatrick J., 1994, Evaluating Training Programs: The Fourth Levels, Berrett-Koehler Publishers, San Francisco.

Kowalski T., 2006, Wybrane aspekty szkoleń w samorzadzie terytorialnym, Studia Lubuskie, nr 2.

Koziński J., Listwan T., 2005, Podstawy zarzadzania organizacja, Wydawnictwo Forum Naukowe, Wrocław - Poznań.

Kubisz M., 2010, Rozwój umiejętności i szkolenia w ramach MSP, 2010, OECD, Ministerstwo Rozwoju Regionalnego, Warszawa. 
Kwiatkowska-Ciotucha D., 2013, Zewnętrzne instrumenty wspomagania rozwoju kompetencji pracowników $w$ kontekście konkurencyjności przedsiębiorstw, Wydawnictwo Uniwersytetu Ekonomicznego we Wrocławiu, Wrocław.

Molek-Winiarska D., 2016, The application of European Framework Agreement on work-related stress in the context of Polish enterprises, Journal of Economics and Management, vol. 26(4), pp. 71-87.

Morley M., Slavic A., Poór J., Berber N., 2016, Training practices and organizational performance: a comparative analysis of domestic and international market oriented organizations in Central \& Eastern Europe, Journal of East European Management Studies, vol. 21, no 4, pp. 406-432.

Pauli U., 2014, Rola szkoleń pracowników w rozwoju matych $i$ średnich przedsiębiorstw, Wydawnictwo Uniwersytetu Ekonomicznego w Krakowie, Kraków.

Pautu S., Dogaru M., 2013, The main deficiencies in the implementation of the Sectoral Operational Progamme Human Resources Development, Annales Unversitatis Oeconomica Apulensis Series, no 1, pp. 509-515.

Podgórniak-Krzykacz A., Kalisiak-Mędelska M., 2016, Instrumenty zarządzania zasobami ludzkimi w świetle ustawy o pracownikach samorzadowych $i$ ich implementacja, Zarządzanie Zasobami Ludzkimi, no 1/2016, pp. 57-77.

Program Operacyjny Wiedza Edukacja Rozwój, 2014, Ministerstwo Infrastruktury i Rozwoju, Warszawa.

Sprawozdanie końcowe z wdrażania Programu Operacyjnego Kapitat Ludzki 2007-2013, 2017, Ministerstwo Rozwoju, Warszawa.

Sprawozdanie z wdrażania Programu Operacyjnego Kapitat Ludzki 2007-2013 za I pótrocze 2015 roku, 2015, Ministerstwo Infrastruktury i Rozwoju.
Tomé E., 2012, European Social Fund in Portugal: a complex question for human resource development, European Journal of Training and Development, vol. 36, no 2/3, pp. 179-194.

Tomé E., 2013, The European Social Fund: a very specific case instrument of HRD policy, European Journal of Training and Development, vol. 37, no 4, pp. 336-356.

Tracz-Krupa K., 2015, Analiza wpływu Europejskiego Funduszu Spolecznego na rozwój zasobów ludzkich, Prace Naukowe Uniwersytetu Ekonomicznego, nr 380.

Tracz-Krupa K., 2017, Employee development in organizations within European Social Fund in Poland in the perspective 2007-2013 - research findings, [in:] Tome E., Sousa M.J., Costa S. (eds.), Proceedings of the 18th International Conference on Human Resource Development Research and Practice across Europe, Universidade Europeia - Escola de Ciencias Sociais e Empresariais, vol. 2, Lisbon.

Trochimiuk R., 2013, Rozwój zawodowy pracowników w malych i średnich przedsiębiorstwach, Zarządzanie Zasobami Ludzkimi, no 3-4, pp. 127-138.

Turek K., Worek B., 2015, Ksztatcenie po szkole. Edukacja a rynek pracy, t. III, Polska Agencja Rozwoju Przedsiębiorczości, Warszawa.

Westhead P., Storey D.,1997, Training Provision and the Development of Small and Medium-size Enterprises, DfEE Publications Research Report, no 26.

Zaman G., Georgescu G., 2014, The absorption of EU structural and cohesion funds in Romania: international comparisons and macroeconomic impact, Munich Personal RePEc Archive, no 57450 , pp. 1-18.

\title{
ROZWÓJ PRACOWNIKÓW ZE ŚRODKÓW EUROPEJSKIEGO FUNDUSZU SPOŁECZNEGO (EFS) Z PERSPKEKTYWY BENEFICJENTA OSTATECZNEGO (BO) W POLSCE W LATACH 2007-2013 - WYNIKI BADAŃ EMPIRYCZNYCH
}

\begin{abstract}
Streszczenie: Celem niniejszego artykułu jest diagnoza rozwoju pracowników w ramach środków z Europejskiego Funduszu Społecznego w Polsce w okresie programowania 2007-2013 z perspektywy beneficjenta ostatecznego, a także wskazanie obszarów dysfunkcjonalnych i sposobów ich usprawniania. Badania zrealizowano w 2017 r. metodą CATI na grupie 200 pracowników organizacji, zarówno publicznych, jak i prywatnych, które otrzymały wsparcie unijne na realizację działań szkoleniowo-rozwojowych. Wnioski z badań dotyczą oczekiwań pracowników względem rozwoju w miejscu pracy, możliwości oferowanych przez pracodawców, rodzajów i form szkoleń finansowanych z EFS, w których pracownicy brali udział, a także badania efektywności szkoleń według D. Kirkpatricka, korzyści z udziału w projekcie unijnym z perspektywy pracownika oraz sposobów wykorzystania przez pracodawców kwalifikacji pracowników zdobytych w ramach projektu unijnego.
\end{abstract}

Słowa kluczowe: rozwój pracowników, beneficjent ostateczny, Europejski Fundusz Społeczny. 